\title{
A Study of Conceptual Development on Internet-Based Academic Service (Internship Program Related) as A Manifestation of UNNES the Conservation University
}

\author{
Mohammad Arif Ali $^{1 *}$, Sugiarto ${ }^{2}$, Gustiana Mega Anggita ${ }^{3}$, Siti Baitul Mukarromah ${ }^{4}$, \\ Yuli Dewi Lestari ${ }^{5}$, Dewi Marfu'ah Kurniawati ${ }^{6}$, Isna Lailatuz Zahroh ${ }^{7}$, \\ Teddy Firdyansyah ${ }^{8}$, Yazid Rizki Khamdani ${ }^{9}$ \\ \{hiarifalikhan@mail.unnes.ac.id¹, sugiarto.edu@mail.unnes.ac.id ${ }^{2}$, mega.anggita@mail.unnes.ac.id ${ }^{3}$ \}
}

Universitas Negeri Semarang, Semarang, Indonesia ${ }^{1,2,3,4,5,7,8,9}$, Universitas Diponegoro, Semarang, Indonesia ${ }^{6}$

\begin{abstract}
An embodiment of the quality management system, minimizing the errors lead to complaining, Easiness, and Effectiveness to access or to run any kind of activity, also facilitating all people who are engaged in the academic system are some of the most important reasons why we should always improving the academic service quality. On another hand, an internship is one of the challenging programs that all university students must accomplish, because it is the integration of academic environment and real job ambient that involving not only lecturer and student but also the mentor, administration staffs, and other people like the client or customer. Moreover, since the pandemic Covid19 has been attacking all over the globe, the manual administration things nowadays must adapt and migrate to an online service. Therefore, A new system that could become the platform to accommodate all the needs related to academic services especially for the internship program seems a promising solution.
\end{abstract}

Keywords: quality service; digital era; climate change.

\section{Introduction}

As a conservation university, Universitas Negeri Semarang (UNNES) acknowledges a lot of manifestations from conservation values, and conservation's perspective includes the ideology, principal, and behaviors (preservation, maintenance, care, preservation, also development) which implemented in daily life on natural resources and socio-cultural values, and more particularly in academic service. Those principals become the soul of three fundamentals activities in higher education at UNNES.

Since Coronavirus disease (COVID-19) has been attacking Indonesia, it challenges many sectors not only health, economic, tourism, but also education. All educational levels must be responsive and quick enough to adapt to this global pandemic challenge. In 2020, the Department of Sports Science, Faculty of Sports Science, UNNES issued the policy that every sports science student who engages with the internship program must carry out in their own city, the reason was trying to suppress the increasing number of infected people in Indonesia. Meanwhile, education activities still can be performed. 
Regarding the previous online system called sistem layanan akademik program studi ilmu keolahragaan (SILAPOR)/academic service which Department of Sports Science UNNES launched in 2020, it makes a better change in general service related to many bureaucracies such as the research topic submission, final defense, tittle verification, plotting advisor, and many more become feasible, effective and much easier.

Based on the brief elucidation above, a study of conceptual development on an academic service system must to generate. Hence, this generation may lead to a manifestation of UNNES the conservation university as well as an adaptation to global pandemic Covid-19.

\section{Methods}

This paper is a part (to find) of the series stage in research and development. While, methods for research and development were applied in this study, which aims to find, fix, develop, produce, to test, until a standardized new product successfully created. At the stage to find we did research and collecting the related information. Tabulation and compilation for all related data; detailed examination for chosen data and construction to profound a new concept; conclusion generating to end the process of traditional literature study are steps we did perform. Furthermore, original studies, Policies of the University Related to the topic, and other references were used as materials and supporting data to generate the appropriate concept to solve the issue.

\section{Results and Discussion}

\subsection{The Conservation Values of Universitas Negeri Semarang}

Any effort that performed to maintain, sustain, and protect any form of thing could be a living organism, goods, environmental-related things, or even a system can be called conservation. More specifically, the process of affecting a person's emotions, attitudes, knowledge, and behavior is known as conservation education. This process required talented also skilled educators who adaptive to any changes or different situations include modify their techniques, methods, and assessments to achieve their determined goals.

Universitas Negeri Semarang as a conservation university has seven pillars to implement the program, are: 1) biodiversity conservation; 2) green architecture and internal transportation systems; 3) waste management; 4) Paperless policy; 5) clean energy; 6) conservation ethics, arts, and culture; and 7) conservation regeneration. ${ }^{1}$ The paperless policy pillar aims to efficiently implement conservation-oriented administration. The paperless policy pillar program is implemented through optimization of information technology-based systems, efficient use of paper, utilization of recycled paper, and use of environmentally friendly paper. ${ }^{2}$

Universitas Negeri Semarang aims to develop eleven conservation values as its characteristics, they are: 1) spiritual; 2) honest; 3) smart; 4) fair/sportif; 5) responsible; 6) care; 7) tolerant; 8) democratic; 9) nationalist; 10) strong, and 11) polite. ${ }^{3}$ Further, each faculty at Universitas Negeri Semarang must to have one of eleven conservation values as its specific characteristic, and Sportif becomes the main characteristic of the Faculty of Sports Science, Universitas Negeri Semarang in their all academic services. The embodiment of Sportif 
value in academic service could be many forms, but the simple description is once the system of academic services has been integrated, transparency, and accountable.

\subsection{SITIKA as the Promising Solution in the Digital Era}

Jill Shepherd in his study state that the digital era is beyond the evolution system of technology because it turns our knowledge very high, and can be out of human control, the worst this era is a time in which our lives become more difficult to manage. ${ }^{4}$ In fact, every aspect of life now has been merging with the need of updating technology. This revolution started about four decades ago. Begins with the internet, then followed by mobile devices, then social networking, big data, data clouds, even the revolution work practices in healthcare and education. Additionally, in the last three year as well as the Corona Disease in 2019 become the Global Pandemic, many aspects of life urge to adapt rapidly. One of many effects from Covid19 is the industrial era has been shifting into the digital era. There is no exception for the education industry.

A different generation of students from time to time i.e. Millenial versus Gen-Z, and their own unique characteristics, attitudes, and behavior make us considering and must choose what the best and appropriate approach to facilitate them to learn. ${ }^{5}$ In line with this study, as an effort, the Department of Sports Science has been developing a system to facilitate students. Currently, they are at the stage of migration from manual service into systemic digitalization services. The current upcoming system which is developed by the Department of Sports Science called "Sistem Praktik Kerja Lapangan (SITIKA)" as known as the internship system at program study level is expected to be the appropriate solution.

In the education industry, using an online system on the ways to run things-related process are so easy and many benefits from it, such as better time management, improving collaboration, improving communication, global perspective, refined critical thinking-skill, new technical skill, performed self-motivation, and flexible in avenue. ${ }^{6}$ Moreover, adopting from key performance indicators for online education by Jens Ischebeck, SITIKA as the online academic service must have the following indicators to ensure the system quality are: 1) the number of students who performs the internship program each batch;2) demographic information about students, it will help for any official announcement-related internship; 3) number of partner institutions, it will helps on the development and partnership programs; 4) online evaluation form for partner institution, to help improving the quality for the next batch, and 5) online attendance for students to evaluate the rate of their engagement during the internship program. ${ }^{7}$

\subsection{The Use of Technology for Internship Program}

An internship program is designed to encourage students to experience the real work-world, by implementing all theories they have been learning in the class to the real duty either administration kinds of stuff or practical work, and this program has been evaluated to have positive effects on the professional growth and students' ${ }^{6}$ skill. ${ }^{8}$ While, based on the students ${ }^{6}$ point of view on their satisfaction with the internship program, there are some crucial factors that positively contributing: feedback, autonomy, supervisor (lecturer) and mentor, academic preparedness, flexible working hours, student self-initiative, location, and skills variety. ${ }^{9}$ 
Technology becomes part of the society in order to make things easier with less time consuming, and low-cost budget. This role in the educational industry obviously can be seen as the relationship between teacher to student, or student to student improved; it makes the learning process more fun and insightful, and facilitate students to collaborate with their classmate. ${ }^{10}$ Hence, nowadays the use of technology is considered as the best approach to deliver teaching materials before, during, and probably after Covid-19 as the hybrid methods of teaching.

Once SITIKA is launched, it will definitely support UNNES in improving and sustaining the academic services conservation. As the optimization of academic services technology-based systems, SITIKA is believed will makes better changes related to the administration of the internship program by 1) allow students to submit their proposal via the system, which means they do not need to print out the document (paperless); 2) allow the institution to issue any related document through the system; 3 ) allow either the advisor (lecturer) and the mentor to do supervision or even submit their final score related to student's performance by online.

\section{Conclusion}

Sportif is one of the eleven conservation value become the main characteristic of the Faculty of Sports Science, Universitas Negeri Semarang, and "Sistem Praktik Kerja Lapangan (SITIKA)" as known as the internship system at program study level is expected to be the appropriate solution, meanwhile SITIKA is one of the manifestations of paperless policy as digitalization academic services going into the right decision.

Acknowledgments. This paper is part of the instuctional study entittled "Pengembangan Sistem Praktik Kerja Lapangan (SITIKA) sebagai Upaya dalam Mendukung UNNES Kampus Konservasi“ ${ }^{\text {“ }}$. This study was granted by Faculty of Sports Science, Universitas Negeri Semarang Dana DIPA FIK UNNES Year 2021.

\section{References}

[1] Yuniawan T. Model Wacana Berwawasan Nilai-Nilai Konservasi Berbasis Ekolinguistik Sebagai Pengayaan Materi Ajar Mata Kuliah Pendidikan Lingkungan Hidup. J Penelit Pendidik Unnes. 2016;33(2):189-95.

[2] Rektor UNNES. Tata Kelola Kampus Berbasis Konservasi. Peraturan Rektor Nomor 27 Tahun 2012 Semarang; 2012.

[3] Ridlo S. Pengembangan karakter Konservasi Untuk Mahasiswa Biologi Program PPG-SM3T. J Pendidik Biol. 2016;8(1):17-26.

[4] Shepherd J. What is the Digital Era? In: Doukidis G, Mylonopoulos N, Pouloudi N, editors. Social and Economic Transformation in the Digital Era. Pennsylvania: IGI Global; 2004. p. 1-18.

[5] Hashim H. Application of Technology in the Digital Era Education. Int J Res Couns Educ. 2018;1(2):1-5. 
[6] Miller K. The Benefits of Online Learning: 7 Advantages of Online Degrees [Internet]. 2019 [cited 2021 Apr 29]. Available from: https://www.northeastern.edu/graduate/blog/benefits-of-onlinelearning/

[7] Ischebeck J. Key Performance Indicators For Online Education In Sub-Sahara Africa [Internet]. 2017 [cited 2021 Apr 29]. Available from: https://elearningindustry.com/key-performanceindicators-online-education-in-sub-sahara-africa

[8] Anjum S. Impact of Internship Programs On Professional and Personal Development of Business Students: A Case Study From Pakistan. Futur Bus J. 2020;6(2):1-13.

[9] Hussein F, Lopa M. The Determinants of Student Satisfaction with Internship Programs In The Hospitality Industry: A Case Study In The USA. J Hum Resour Hosp Tour. 2018;17(4):502-27.

[10] Raja R, Nagasubramani PC. Impact of Modern Technology In Education. J Appl Adv Res. 2018;3(S1):S33-5. 